\title{
Crisis
}

Abstract The seven in-between years ended with a banking crisis, which brought Japan to the brink of a systemic meltdown. The crisis was contained with massive capital injections in banks, much-enhanced resolution tools, stronger disclosure and provisioning, and the new supervisory agency. The crisis, however, resulted in credit crunch, recession, bankruptcy, unemployment, and suicide and left deep scars in the Japanese economy and society.

Keywords Bank run · Resolution tools · Disclosure · Provisioning · Supervisory culture $\cdot$ Credit crunch

At around ten in the morning on Wednesday November 26, 1997, telephones at the headquarters of the Bank of Japan and the Ministry of Finance started to ring with emergency reports from their local offices, and from bankers. ${ }^{l}$ Queues of depositors were formed in front of bank branches in Wakayama, Utsunomiya, Toyama, Sapporo, Tokyo, Nagoya, Osaka, and Fukuoka. Bank equity prices started to tumble, and the short-term money market rate jumped up.

The anxiety accumulated in the minds of the nation through the series of bank failures was reaching a critical level. According to Nakaso (2001), 
who then was the director in charge of financial stability at the Bank of Japan, "This was probably the day that Japan's financial system was closest to a systemic collapse." Later, a Finance Ministry high official recalled the day and said, "We peeped into the boiling pot of the Hell." 2

The Ministry instructed banks to contain the queues by giving depositors numbered cards and guide them to meeting rooms inside branches, lest the scene of a queue should lure other depositors to join the run. The Bank of Japan dispatched enormous amount of cash, since depositors would panic if a branch should run out of cash. In the evening of the day, the minister of finance and the governor of the Bank of Japan issued a joint statement confirming that deposits and interbank exposures would be protected. The heads of the local branches of the Ministry and the Bank in the affected regions held joint press conferences to calm the depositors. Banks showed video-taped press conferences at branches.

TV stations refrained from broadcasting the queues and newspapers refrained to report. There were no social networking services or internet banking in those days. The queues subsided in the following days. But many did not believe that it was the end of the horror. A psychiatrist Nakai Hisao describes his feeling in mid-December as follows: "I felt like a passenger on a ship, who found that a torpedo was heading straight towards the ship. Knowing that there was no way to avert it, I held the handrail tight and waited for the moment of impact."3

\section{Political Leadership}

Political leaders sensed the nation's inquietude earlier than the day of the nationwide queues. Four days after the collapse of the Hokkaido Takushoku Bank, former prime minister Miyazawa submitted to the prime minister a proposal to use public funds. On the next day, another ruling party heavyweight Kajiyama Seiroku also submitted a proposal. The day after the collapse of the Yamaichi Securities and the day before the queue day, the ruling Liberal Democratic Party established the Emergency Headquarters for Financial Stability and nominated Miyazawa as its head.

Miyazawa proposed to use public funds to assist resolution of failed banks by supporting purchasing banks. Kajiyama proposed preemptive capital injection to banks which have not yet failed. In Miyazawa's proposal, the government was to guarantee bonds issued by the Deposit 
Insurance Corporation, and, in Kajiyama's, to grant funds to the Corporation. Miyazawa did not mention a specific amount of money, and Kajiyama, ten trillion yen.

The ruling party proposal agreed in December was beefed up to more than the sum of the two proposals. The government will guarantee the borrowing by the Deposit Insurance Corporation and provides funds to it. ${ }^{4}$ The money can be used both for assisting purchasers of failed banks and for supporting living banks. The amount of money was increased to thirty trillion yen.

A Finance Ministry high official later recounted, "While deliberating on the proposal, the ruling party started to realize that the public opinion was now not so hostile to the use of public funds. Then the party turned passionate about the project and started to think that, if they should do it, they should do it big. Politicians are good at grasping emerging opportunities. I believe the bureaucracy is for continuity and the politics is for a jump."

Nakai Sei, who struggled to sustain the system at the Ministry during the in-between years, argues, "The nation could accept the use of public funds only after a financial crisis became a reality and the economy was brought to the brink of a panic." 5

\section{CApital Injections and Raids on Regulators}

The Finance Ministry officials worked day and night and, in January 1998, submitted to the national Diet bills implementing the ruling parties' recommendations.

The Diet passed the two new laws on 16 February. The Japanese banks' accounting year ends at the end of March. Just in time for this deadline, the 1.8 trillion-yen assistance to the banks purchasing the Hokkaido Takushoku Bank was financed based on one of the two laws. Preemptive capital injections were made to 21 banks based on the other law. The amount of injected capital, 1.8 trillion yen, was totally inadequate to resurrect 21 banks, most of them much larger than Hokkaido Takushoku, but the injection demonstrated that the government stood ready to support them. A crisis, which had been feared to happen at the end of March, was averted by a hairsbreadth.

According to Nishino (2019), when the ruling party started to discuss the use of public funds, officials at the Banking Bureau of the Ministry 
of Finance was wary, thinking "If the use of public funds gets discussed, then we will be hanged, drawn, and quartered."

The prediction was not too much off the mark. One day after the submission of the bills to the Diet, the coalition ruling parties formally agreed to break up the Ministry of Finance into the fiscal policy part and the financial supervision part sometime in 1998. The decision concluded the deliberations lasted for two years since February 1996, when the use of public funds to resolve Jusens ignited the review on the Ministry.

Amid the Diet deliberations, the Tokyo Prosecutors' Office raided the Ministry headquarters. The Ministry's two bank inspectors were arrested on the charges of having been entertained by banks. The minister and the vice minister resigned, and one senior inspector committed suicide.

While a newly created panel examined major banks' applications for capital injections, other two Finance Ministry officers and a Bank of Japan director were arrested, the Ministry's another officer committed suicide, the Prosecutors' Office raided the Bank of Japan headquarters, and the governor and the deputy governor of the Bank resigned.

One month after the capital injection, the Ministry fired the director general of the Securities Bureau and the deputy director general of the Banking Bureau and imposed disciplinary measures on other 110 officers for being entertained by financial institutions. The Bank of Japan took measures on 98 officers.

\section{SUMMER I998}

In 1998, the rainy season started earlier than usual. A rainy season usually lasts for one month and a half, but in that year, it continued to rain throughout the summer. In some parts of Japan, it was difficult to identify when the season ended.

On Friday June 5, 1998, a Japanese monthly magazine carried an article with an eerie title "The failure of the Long-Term Credit Bank of Japan (LTCB) will trigger a terrifying process to weed out weak banks." On the following Monday, the Financial Times reported on problems at the LTCB. On Tuesday, the London branch of the joint venture investment bank formed by the LTCB and a foreign bank sold 1.4 million LTCB shares. Market participants thought that the foreign bank, which agreed on an alliance with the LTCB about a year ago, was now turning its back to its partner. 
The LTCB share price tumbled to less than a quarter of the price seen in May. Run on the bank ensued both in branches in Japan and in money market in London. The foreign alliance partner gained the right to acquire the full ownership of three joint venture firms based on the "distress warrant clause" added to the joint venture agreements three month before, which used the LTCB share price as the trigger.

The LTCB was established in 1952 under the newly enacted LongTerm Credit Bank Act. It had the privilege to issue debentures, which was given to only a handful of banks, and financed investments in factories and equipment. It substituted Japan's immature capital market and supported the country's rapid economic growth in the 1960s. But by the mid-1980s, the Japanese manufacturers stopped building factories in Japan, and large companies started to finance themselves in the overseas capital market. The bank's unique raison d'être largely disappeared.

The bank considered several options. One was to downsize and transform itself to a boutique investment bank, building on its strength in the capital market and cross-border transactions. Another was to expand itself to be like other ordinary commercial banks. The bank tried to pursue both options, but the former was frustrated by the Japanese version of Glass-Steagall. The latter faced the lack of a large branch network needed to lend to SMEs and an affiliated keiretsu group needed to lend to big businesses.

Toward the end of the asset price bubbles, the LTCB and its affiliated non-bank lenders found opportunities for growth and profit in loans to emerging real estate developers. Its balance sheet swelled to the size equivalent to that of Citicorp or Société Générale, making it the world's 20th largest. After the collapse of the real estate price bubble, swelled loans went sour.

According to Suzuki (2009), who served as the bank's last CEO, the LTCB first focused on the resolution of bad loans extended by the bank itself, and then from 1994 expanded the scope of its efforts to the restructuring of its affiliated non-bank lenders. The eight years of struggle with bad loans were like "trying to climb up vertical cliffs of a rocky mountain one after another." He refers to the involvement of yakuza organized crimes which supported borrowers and obstructed the bank, very illiquid real estate market and lack of secondary markets for loans, slow and cumbersome legal process needed to auction collateral real estates, and other difficulties. The LTCB bankers, who had lent only to the cream of 
the Corporate Japan for decades, had to deal with totally different types of people.

The series of events in June 1998 happened at the most inconvenient period for both the government bureaucracy and for the political leadership to fulfil their crisis management roles. In the month, the Ministry of Finance was teared apart. Regulatory policy stayed with the Ministry and supervisory power was vested in the newly created Financial Supervisory Agency (JFSA). The new Agency was just organizing itself and was in short even of stationary, not to speak of experienced staff. There were some doubts on which of the two, the Ministry or the Agency, should take the lead in managing the crisis.

In July, the ruling Liberal Democratic Party lost heavily at the Upper House election. The Party president cum the prime minister resigned, and the party's new presidency was contested between Kajiyama Seiroku, who argued for a "hard-landing" policy of resolving bad loans in two years, and Obuchi Keizo, who argued for what could be called a "soft-landing" policy of supporting the economy by fiscal stimulus and won the contest. Having lost the majority at the Upper House, the ruling party could not enact a law without supports by oppositions.

Deciding on the resolution of an internationally active big bank under the condition of a system-wide distress cannot be an easy task anyway, but in this case the process coincided with the distress in the government. The LTCB had been put in limbo for more than four months.

During the four months, the debate continued both on the design of the country's resolution framework in general and on the fate of the LTCB in particular.

On the resolution framework, the ruling party was for the use of a bridge bank, and the opposition parties were for introducing a temporary nationalization approach. On October 12, the Diet enacted a bill to introduce both the bridge bank approach and the temporary nationalization approach. In addition, on October 16, the Diet enacted a bill to earmark 25 trillion yen for preemptive capital injections, 18 trillion yen for resolving failed banks, and 17 trillion yen for depositor protection, doubling the available amount of public funds to 60 trillion yen, or $11 \%$ of the annual GDP.

On the LTCB, there were debates involving the ruling party, the opposition parties, the Ministry of Finance, and the Financial Supervisory Agency. Some were leaning toward persuading a sounder bank to rescue the LTCB, while others were for resolving it as a failed bank. 
The bank's fate took the latter course, as a candidate rescuing bank refused to step in, even though the prime minister and the finance minister themselves tried to persuade it in person. On October 23, the LTCB was nationalized as a failed bank. Later, the bank was assessed to be of negative net worth amounting to 2.7 trillion yen, or $11 \%$ of its total asset. In December, the Nippon Credit Bank, another of the three long-term credit banks, was nationalized.

In December, the Financial Reconstruction Commission was established to administer bank resolution and capital injection. In January 1999, the Commission announced that banks should provision at least for around $15 \%$ of the outstanding uncollateralized amount of substandard loans and $70 \%$ of doubtful loans. By the end of March, major banks had 7.5 trillion yen of capital injected by the Commission and raised 2.6 trillion yen in the market. The crisis started in November 1997 largely subsided in March 1999.

But the immediate remedial measures to contain symptoms can stay credible only when accompanied by longer-term policies that address the diseases and deeper causes. A crisis can provide a rare opportunity for painful but needed reforms. Many important steps had been taken by March 1999 as described below, but more had to be done, as will be described in Chapter 6.

\section{Evolution of Resolution Approaches}

During the crisis period from November 1997 to March 1999, Japan gained and lost many things. Among the most important gains was a much-enhanced toolkit for resolution (Table 5.1).

The resolution approaches, which initially covered only failed banks, were expanded to cover failing banks and distressed banks in 1998. The coverage of protection was expanded from insured deposits to all liabilities in 1996. Approaches which can maintain the legal entity was introduced in 1998 to limit disruptions in derivatives, lending, and other markets. The previous set of tools had been able to deal only with idiosyncratic failures of non-systemic banks, but the toolkit was now capable of addressing system-wide distress and resolving internationally active systemic banks. 
Table 5.1 Evolution of resolution approaches

\begin{tabular}{|c|c|c|c|c|c|}
\hline Approaches & $\begin{array}{l}\text { Liquidation } \\
\text { without deposit } \\
\text { insurance }\end{array}$ & $\begin{array}{c}\text { Liquidation } \\
\text { with deposit } \\
\text { insurance }\end{array}$ & $\begin{array}{l}\text { PÉA with } \\
\text { financial } \\
\text { assistance }\end{array}$ & $\begin{array}{l}\text { Temporary } \\
\text { nationalization }\end{array}$ & $\begin{array}{l}\text { Preemptive } \\
\text { capital } \\
\text { injection }\end{array}$ \\
\hline $\begin{array}{l}\text { Introduced } \\
\text { in }\end{array}$ & - & 1971 & $\begin{array}{l}\text { Limited } \\
\text { assistance } \\
1986, \\
\text { Unlimited } \\
\text { assistance } \\
1996\end{array}$ & $\begin{array}{l}\text { October } \\
1998\end{array}$ & $\begin{array}{l}\text { February } \\
1998\end{array}$ \\
\hline $\begin{array}{l}\text { Banks to be } \\
\text { resolved }\end{array}$ & Failed bank & & & $\begin{array}{l}\text { Failed or } \\
\text { failing bank }\end{array}$ & $\begin{array}{l}\text { Distressed } \\
\text { bank }\end{array}$ \\
\hline $\begin{array}{l}\text { Insured } \\
\text { deposit }\end{array}$ & Not protected & Protected & & & \\
\hline $\begin{array}{l}\text { Uninsured } \\
\text { debt }\end{array}$ & Not protected & & Protected & & \\
\hline Equity & Invalidated & & & & Diluted \\
\hline Legal entity & Liquidated & & & Kept & \\
\hline Management & Replaced by liqu & aidator & $\begin{array}{l}\text { Fired on } \\
\text { transfer } \\
\text { Replaced by } \\
\text { financial } \\
\text { administrator } \\
(1998-)\end{array}$ & $\begin{array}{l}\text { Replaced by } \\
\text { new team }\end{array}$ & $\begin{array}{l}\text { Recovery } \\
\text { plan } \\
\text { monitored }\end{array}$ \\
\hline Use cases & $\begin{array}{l}\text { BCCI Tokyo } \\
\text { branch (1991) } \\
\text { Sanyo } \\
\text { Securities } \\
\text { (1997) }\end{array}$ & & $\begin{array}{l}177 \text { banks, } \\
\text { shinkin } \\
\text { banks, and } \\
\text { credit } \\
\text { cooperatives } \\
(1991-2001) \\
\text { Incubator } \\
\text { Bank of } \\
\text { Japan (2010, } \\
\text { with limited } \\
\text { assistance) }\end{array}$ & $\begin{array}{l}\text { LTCB } \\
(1998) \\
\text { NCB (1998) } \\
\text { Ashikaga } \\
\text { Bank (2003) }\end{array}$ & $\begin{array}{l}21 \text { banks } \\
(1998) \\
15 \text { banks } \\
(1999) \\
19 \text { banks } \\
\text { (1999-2003) } \\
\text { including } \\
\text { Resona Bank } \\
(2003)\end{array}$ \\
\hline
\end{tabular}

Source Author's compilation

\section{Disclosure, Provisioning, And Corrective Actions}

With the new resolution approaches and funding arrangements provided, the Japanese authorities were freed from the Catch 22 type predicament and started to introduce framework to recognize and address problems without further forbearance. Disclosure and provisioning standards were 
enhanced, and the treatment of undercapitalized banks was anchored to numerical criteria.

If we are to use the metaphor used by the Nikkei op-ed piece in 1992 cited in Chapter 4, now that the operation theater was set up with a range of surgical tools and with enough blood for transfusion, doctors need not to hesitate making timely diagnosis or prescription.

First, the standards on bad loan disclosure were strengthened. The Financial Supervisory Agency aimed to align the Japanese disclosure standards with those established by the US Securities and Exchange Commission. Previously, only loans in arrears for more than six months and loans lent with interest rates below the official discount rates had been included in the definition of the non-performing loans. Now loans in arrears for more than three months and loans lent with interest rates below the market rates were included. The reported outstanding amount of bad loans of major banks at the end of March 1998 was 16 trillion yen under the previous standards and 22 trillion yen under the new standards. The disclosure on a consolidated basis was made a legal obligation with penalties for derogations. Common minimum disclosure items were specified, and their definitions were clarified by the authority. ${ }^{6}$

Second, loan loss provisioning was strengthened. The amount of annual loss resulting from bad loan provisioning, sales, and write off jumped from 8 trillion yen in fiscal year 1997 to 13 trillion yen in FY 1998, and 14 trillion yen in FY 1999. Previously, only the amount unrecoverable had to be written off, and provisioning on doubtful loans beyond the predetermined ratio (3\%) was at banks' discretion. In 1998, provisioning for doubtful loans was made mandatory, and as mentioned above, the Financial Reconstruction Commission announced in January 1999 that banks should provision at least for around 15\% of the outstanding uncollateralized amount of substandard loans and $70 \%$ of doubtful loans. Before, provisioning required regulators' prior approval, but, starting from fiscal year 1998, banks were mandated to make proper provisions and write-offs on their own responsibility. Regulators would not provide ex ante approval. They conduct ex post review only.

Third, a framework of prompt corrective action was introduced for internationally active banks from April 1998 and for other banks from April 1999. The framework prescribed regulatory action according to banks' capital adequacy ratio. A bank operating slightly below the minimum ratio will be required to submit a plan to augment its capital base, whereas a deeply undercapitalized bank may be ordered to terminate 
its baking business. The framework was initially proposed by the Ministry of Finance in 1995, and a relevant law was passed in 1996. The Ministry's effort provided the newborn Agency with a transparent framework for regulatory actions.

\section{New Supervisory Culture}

A new supervisory authority, the Financial Supervisory Agency (JFSA), was inaugurated in June 1998 amid the turmoil surrounding the LTCB. It started with totally insufficient resources but created a new supervisory culture.

The Agency was responsible for the supervision of banks, insurance companies, broker-dealers, and asset managers and the surveillance of the capital market of what then was the second largest economy in the world. If compared with US regulatory authorities, the Agency's scope of responsibility corresponded to that of the OCC, the supervision division of the FRB, part of FDIC, state bank and insurance regulators, SEC, and part of CFTC. But, despite being amid a crisis, it had only 403 staff members at its headquarters. In early days of the Agency, the deputy head of the Agency Hamanaka Hideichiro used to say, "If a staff member has got only two different assignments, he should be ashamed of not doing enough. Three may be acceptable, and four can qualify him as hard-working."

The Finance Ministry had very few professional lawyers, accountants, economists, or actuaries to begin with. Moreover, experienced regulators who had been entertained by banks could not been transferred to the new Agency. Some at the Agency's leadership positions had little previous experience of supervising financial institutions. Computers were slow, printers were scarce, and paper, pencils, and highlighter pens were in short supply. In the middle of the negotiations on Basel II, the overseas travelling budget was depleted.

More importantly, the new Agency was little known to the nation and was without any accumulated moral authority or reputation capital. Even on matters within the jurisdiction of the JFSA, many congressmen preferred to discuss with the Ministry of Finance rather than with the obscure new agency. A newspaper carried a cartoon depicting officers lined up on the deck of a big warship, who waved their hands at a small boat being hanged down from the warship to a turbulent sea.

But the inaugurate staff members, who later were dubbed as Pilgrim Fathers, were filled with frontier spirits. There was a clear break in the culture between the big warship and the small boat. The latter's culture 
was closer to a start-up venture than to a big organization with power and history.

On the day of the inauguration, the prime minister instructed Commissioner Hino Masaharu, the new head of the Agency, to focus on ex post reviews, not on ex ante administrative guidance. He demanded that the Agency's activities be fair and transparent, that staff members uphold high ethical standards and re-establish trusts on regulators, and that the Agency do utmost to facilitate resolution of bad loans held by financial institutions.

Responding to this request for a clean break from the previous banking supervision, Commissioner Hino, a former criminal prosecutor, pledged in his inaugural press conference to conduct fair and transparent supervision based on articulate and transparent rules and standards. The Agency shall conduct rigoros and effective on-site inspections and off-site monitoring and act on facts and evidence gathered.

On the day, the director general Gomi Hirofumi of the on-site inspection department instructed inspectors as follows:

The nation doubts if you discharge your responsibility properly. The only thing you need to do now is to report back what you saw on the inspection sites without any distortions. You are radiographers and your responsibility is taking accurate $\mathrm{X}$-rays. The diagnosis is the responsibility of doctors, not yours. Forget about any possible consequences of X-rays taken. Don't hesitate. Consolidate what you have seen and report facts. ${ }^{7}$

Gomi also argued that the Agency should disclose information to have it sanitized by airing and sunshine. The director general of the supervision department Inui Fumio had repeatedly mentioned the following three principles to himself and staff members: Never lie, never hide, and never postpone.

Shiga Sakura, who was the head of the international division, learned about a forbearance policy considered within the Agency while he was travelling abroad. Infuriated, he sent to Tokyo a facsimile message with handwritten big letters, stating, "Otto von Bismarck once said, 'Only a fool learns from his own mistakes. The wise man learns from the mistakes of others.' He would consider us worse than a fool." A copy of the message was posted on the wall of the international division for many years. 


\section{Credit Crunch, Recession, Bankruptcy, UNEMPLOYMENT, AND SUICIDE}

At the same time, the crisis left deep scars in the Japanese economy and society. The crisis triggered a severe credit crunch, and it coincided with fiscal austerity and the Asian financial crisis. The combined effects resulted in recession and surges in bankruptcy, unemployment, and suicide.

The failures of major banks and the long queues of depositors around the country in November 1997 scared bankers. They were further intimidated by the scene of the world's 20th largest bank put in limbo for four month and by the new regulators' repeated declaration of the end of forbearance. Bankers rapidly tightened their lending standards, despite the repeated easing of the monetary policy during the period. The difference between the proportions of firms facing "easy" and "tight" bank lending attitude dropped from positive 14 percentage points in the third quarter of 1997 to negative 19 points in the first quarter of $1998 .{ }^{8}$ While only 78 newspaper and magazine articles referred to "credit crunch" in 1996, the number jumped to 2330 in 1997 and then exploded to 15,869 in $1998 .{ }^{9}$ The outstanding amount of bank loans to the non-financial corporate sector, which stayed flat during the in-between years, started to decline.

And the credit crunch coincided with fiscal austerity, on which the government embarked in January 1997. The VAT and income tax were raised in April 1997, and larger share of medical expenses were put on patients in September.

The business cycle had peaked in May. The Asian financial crisis broke out in July and the Japanese banking crisis in November. The fiscal policy had to make a rapid turnabout. The new fiscal consolidation law, enacted early in December, was de facto abandoned later in the month by the decision to cut the income tax.

The real growth rate declined from 3\% in 1996 to 1\% in 1997 and turned negative in 1998. Motonishi and Yoshikawa (1999) estimate that the credit crunch lowered the GDP growth rate by 1.6 percentage points. The government tried to mitigate the credit crunch by expanding the budgets for the public guarantee of loans to SMEs and for the direct lending by government financial institutions each by 20 trillion yen. It also published in November 1998 the largest economic stimulus package in the history. It was composed of tax cuts and infrastructure investments and amounted to $4 \%$ of the annual GDP. The government bond issuance 
almost doubled from 18.5 trillion yen in the fiscal year 1997 to 34.0 trillion yen in the fiscal year 1998 .

The fiscal consolidation law was formally terminated on December 2, 1998, and Moody's Investor Service downgraded the Japanese Government Bond (JGB) on December 17. A newspaper article reported on December 20 that the government-run Fiscal Investment and Loan Program would reduce the purchase of JGBs. The 10 -year JGB rate jumped from less than $0.8 \%$ in early October 1998 to $2.4 \%$ in early February 1999.

But contrary to what happened to the Eurozone in the 2010s, sellingoff of the JGB did not lead to selling-off of Japan. The yen, which was traded at around 135 yen per dollar in early October 1998, rose by a quarter to 109 yen per dollar in early January 1999, exerting further deflationary pressure on the economy.

The Bank of Japan then entered the brave new world of the unconventional monetary policy. It introduced the world's first zero interest rate policy (ZIRP) in March 1999. In April it announced that it would continue ZIRP till the deflationary concern was dispelled, introducing the world's first forward guidance. The 10-year JGB rate declined to $1.3 \%$ in May and the yen depreciated to the level of 120 yen per dollar.

The fiscal stimulus, which doubled the deficit, and the unconventional monetary policy, which had been deployed a decade before the United States and Europe did, were successful in averting an acute deflationary spiral, and the business cycle bottomed in January 1999. Nevertheless, the growth rate in 1999 stayed negative.

The experience highlighted the need to coordinate various elements of economic policy. The Council on Economic and Fiscal Policy was inaugurated in 2001, with the prime minister as its chair and five ministers, the governor of the Bank of Japan, two business leaders, and two economists as its members, and strengthened its role over time.

The annual cases of corporate bankruptcy jumped from 15 thousand in 1996 to 19 thousand in 1998 (Fig. 5.1). The Economic Planning Agency (1999) argues that factors on the side of banks contributed to the increase in corporate bankruptcy cases, particularly in 1998. Although employers tried to maintain employment by reducing overtime, restraining pay, and sacrificing corporate profits, the unemployment rate hiked from $3.5 \%$ in end 1997 to $4.4 \%$ in end 1998 and $4.7 \%$ in end 1999, breaking the record. 
In the post-war Japan, there was a system of implicit chain of support: the Ministry of Finance reigns over and looks after banks, banks monitor, support and, if necessary, intervene in big businesses, big businesses often take advantages of subcontractors but in certain cases protect them, and employers demand full dedication from their employees but in return guarantee lifetime employment. 1998 was the year when this social contract of the post-war Japan was shaken and cracked.

Up until 1997, the annual number of people committing suicide has long fluctuated between 20 thousand and 25 thousand. It, however, jumped to 33 thousand in 1998 and stayed around the level even after the unemployment returned to the pre-crisis level (Fig. 5.1). The crack in the system caused by the crisis was deeply unnerving and painful.

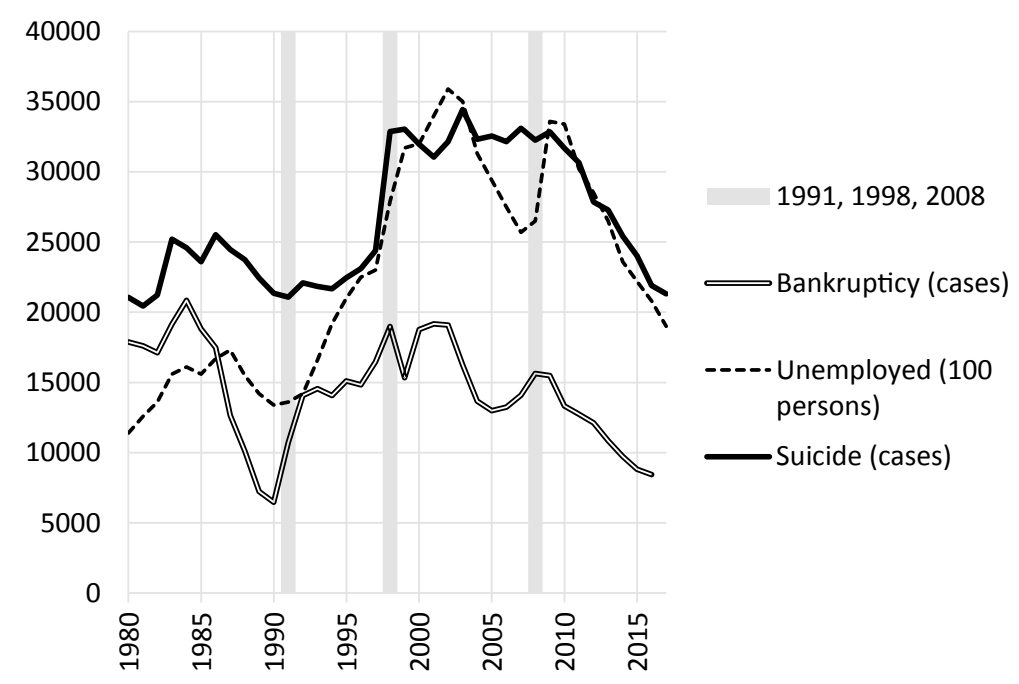

Fig. 5.1 Bankruptcy, unemployment, and suicides (Source Tokyo Shoko Research, National corporate bankruptcies; Statistics Bureau, Labor statistics; and National Police Agency, Number of suicides) 


\section{Moral Hazard and Firefighting}

Japan held off surgery till patients' conditions turn critical and operation theaters could be set up. However, there have been cases in abroad where surgery started before operation theaters were set up.

For example, the International Monetary Fund recommended in 1997 that Indonesia wind down 16 distressed banks immediately, even though a proper safety net had not been in place. The implementation of this recommendation resulted in a major bank run and a systemic meltdown in a country that had no major imbalances before the crisis.

The European leaders announced in October 2011 a package that included a Europe-wide stress test on one hand and a government guarantee of bank term funding and reactivation of national capital injection schemes on the other. They must have intended to prepare operation theaters and conduct surgeries simultaneously. However, the sequence was different when implemented: the stress test went out first, the reactivation of capital injection schemes followed in some countries, and the guarantee was substituted later by the European Central Bank's long-term refinancing operation. If proper sequencing had been taken as initially planned, the crisis would not have posed such existential threat to Euro as seen in late 2011 and early 2012 .

This contrasts with the US sequence in late 2008 and early 2009. The US authorities guaranteed bank debts in October 2008, installed a capital injection program in February 2009, and then published the results of stress tests in May 2009. However, this perhaps could not have happened without the devastating experience of letting Lehman Brothers go in September 2008. It would have been ideal if the guarantee and capital injection program was installed first, stress testing done next, and then Lehman was resolved in an orderly manner.

Japan's case in the 1990s can be considered as slow actions with proper sequencing. The Indonesian case in 1998 and the European case in 2011 can be characterized as quick actions without proper sequencing. The US case in 2008 and 2009 may be considered as a major improper sequencing (Lehman) followed by quick actions with proper sequencing (stress tests).

These episodes seem to imply the need to combine proper framework for problem recognition and policy responses with effective safety nets. The United States and the European Union, however, significantly cut back their resolution toolkits or put strong constraints on the use of 
them after they overcame the Global Financial Crisis. They thought if the bailout options stayed on, banks would expect they would be rescued again and would act recklessly. ${ }^{10}$

Following recommendation of the Financial Stability Board, Japan introduced a framework to resolve banks without using public funds, or so-called bail-in approaches, in 2013. Even after that, however, Japan maintained the bailout options introduced in 1998. The International Monetary Fund did not like this and recommended Japan to impose clearer constraints on the use of bailout tools. ${ }^{11}$

Japanese authority rebutted that the newly designed bail-in tools were yet to be tested in real life, and that, though the bail-in approaches may deal with an idiosyncratic failure of a bank, the world had to solve many issues before the approach become capable to address a system-wide distress involving multiple internationally active systemic banks. Japan had to choose between too-little-too-late and a systemic meltdown in the 1990 s due to the lack of a robust safety net, and it was premature to discard tested tools acquired at great costs in the 1990s at least while the world is still on the journey to end too-big-to-fail. ${ }^{12}$

Several factors may explain the difference between the choices made by Japan and by Europe and the United States. First, Japan formed a national consensus on the need to use public funds in exceptional cases of systemic distress through the protracted nationwide debate in the 1990s. On the other hand, perhaps the period between the outbreak of the Global Financial Crisis and the bailout of systemic banks in the 2000s was too short to form a national consensus in Europe or in the United States.

Second, Japan addressed the moral hazard issues by arresting 44 former CEOs, 63 non-CEO executives, and 27 staff members of 37 failed financial institutions $^{13}$ and by pursuing criminal responsibility of 460 debtors for disturbing the debt collection. It also sued 490 bankers on their civil responsibility. ${ }^{14}$ On the other hand, no CEOs of US major banks went to jail after the Global Financial Crisis.

Third, the Japanese bank CEOs' remunerations were much more modest compared to their western counterparts' astronomical bonuses, both before and after the crisis. It was thus easier for the Japanese authority to persuade the nation that the bailout was not to save bankers but to keep banking function for the national economy.

During a systemic crisis, multiple negative feedback loops can be triggered and exceed the capacity for the market to revert to an efficient equilibrium. As the economist Irving Fisher (1933) argued, a ship under 
ordinary conditions is always near stable equilibrium, but no longer has the ability to return to equilibrium after being tipped beyond a certain angle-instead, it has a tendency to depart further from it.

These negative feedback loops can exist between banks and other banks, between banks and the money and capital markets, between the financial system and the real economy, between the banking system and public finance, and even between the economy and politics. They work through interbank exposures; declines in market liquidity, fire sales, and asset price declines; panic and runs on deposits and other claims; credit crunch, recession, and increased credit costs; and economic performance, confidence in political leadership, and the nation's capability to decide on painful measures in a timely manner.

Overemphasis on these possibilities can work to dissuade painful corrective actions needed to rebuild longer-term resilience of the system. After all, any backstop measures can only buy time and cannot sustain the system forever. The IMF caution on lax use of bailout tools has strong reasons.

At the same time, we should avoid being trapped by politically nice commitments made in peace time and miss opportunities to act promptly with proper sequencing.

In 1999, Tim Geithner and other staff members of the US Treasury compiled "Rubin Doctrine of International Finance," drawing from the Treasury secretary's words and deeds during the Mexican and Asian financial crises. ${ }^{15}$ The doctrine maintains that the only certainty in life is that nothing is ever certain. Accordingly, "Optionality is good in itself." It recognizes that "markets are good, but they are not the solution to all problems." Then how can the public sector address problems which markets cannot solve? The doctrine goes, "Money is no substitute for strong policy, but there are times when it is more costly to provide too little money than to provide too much."

An effective crisis management framework should be equipped with a range of options and enough monetary firepower so that it can contain a crisis beyond markets' self-healing capability. It should incorporate a procedure which can provide flexibility and agility, while ensuring proportionate, accountable, and disciplined use of options. The framework should also ensure that the time bought by money will be used to implement strong policy to address root causes of the crisis and restitute function and discipline of good financial markets. 


\section{Notes}

1. Many of the descriptions of the incidents on November 26, 1997, in this chapter rely on Nishino (2019).

2. Nishino (2019).

3. Nakai, H. (2002).

4. The government first grants government bonds to the Deposit Insurance Corporation and, as the needs to use funds occur, the Corporation will have the bonds repaid by the government.

5. Nakai, S. (2002).

6. The amended Banking Law and the newly enacted Financial Revitalization Law introduced similar but different disclosure obligations in 1998.

7. Gomi (2012).

8. Bank of Japan, Short-term economic survey of enterprises (Tankan survey). Responses by companies of all sizes and all industries and on the current condition.

9. Based on search results from the Nikkei Telecon database.

10. For more on this, see G30 Working Group (2018).

11. International Monetary Fund (2017).

12. See, for example, Mori (2017), who was the commissioner of the JFSA at the time of the speech.

13. Some of those who created bad loans and hid losses escaped charges due to statute of limitations and their successors were charged. Some of the arrested were convicted innocent later at the court.

14. Okuyama and Murayama (2019) and Deposit Insurance Corporation of Japan (2007).

15. Rubin and Weisberg (2003).

\section{REFERENCES}

Deposit Insurance Corporation of Japan (Yokin Hoken Kikou). (2007). Responses to the financial crisis in the Heisei era (Heisei kin'yun kiki eno taiou). Kin'yuu Zaisei Jijou Kenkyuukai.

Economic Planning Agency. (1999). Annual report on the Japanese Economy for 1999 (Heisei 11 nendo ban keizai hakusho).

Fisher, I. (1933). The debt-deflation theory of great depressions. Econometrica: Journal of the Econometric Society, 1(4), 337-357.

Gomi, H. (2012). Financial system turbulence: A monologue by a JFSA commissioner (Kin'yuu douran: Kin'yuuchou choukan no dokubaku). Nihon Keizai Shinbun Shuppansha.

G30 Working Group. (2018). Managing the next financial crisis: An assessment of emergency arrangements in the major economies. Group of Thirty. 
International Monetary Fund. (2017). Japan financial system stability assessment (IMF Country Report No. 17/244).

Mori, N. (2017). A brake pedal alone cannot guarantee safety. In Financial Services Agency. (2018). From static regulation to dynamic supervision: Speeches by Commissioner Nobuchika Mori.

Motonishi, T., \& Yoshikawa, H. (1999). Causes of the Long Stagnation of Japan during the 1990s: Financial or real? Journal of the Japanese and International Economies, 13(3), 181-200.

Nakai, H. (2002). Clear, cloudy, starry, and rainy (Sei yin sei u). Misuzu-shobo.

Nakai, S. (2002). Squint eyed views on the financial sector policy (Yabunirami kin'yum gyosei). Zaikei-shoho.

Nakaso, H. (2001). The financial crisis in Japan during the 1990s: How the Bank of Japan responded and the lessons learnt (BIS Papers No. 6).

Nishino T. (2019). Financial history of the Heisei era (Heisei kin'yum shi). Chukoshinsho.

Okuyama, T., \& Murayama, O. (2019). Deep inside the incidents of the bubble economy (Baburu keizai jiken no shinso). Iwanami-shinsho.

Rubin, R., \& Weisberg, J. (2003). In an uncertain world. New York: Random House.

Suzuki, T. (2009). The extinction of a mammoth bank: Testimony of the last CEO of the LTCB 10 years after (Kyodai Ginko no Shometsu: Chogin Saigo no Todori 10 nenme no Shogen). Toyo-keizai.

Open Access This chapter is licensed under the terms of the Creative Commons Attribution-NonCommercial-NoDerivatives 4.0 International License (http:// creativecommons.org/licenses/by-nc-nd/4.0/), which permits any noncommercial use, sharing, distribution and reproduction in any medium or format, as long as you give appropriate credit to the original author(s) and the source, provide a link to the Creative Commons license and indicate if you modified the licensed material. You do not have permission under this license to share adapted material derived from this chapter or parts of it.

The images or other third party material in this chapter are included in the chapter's Creative Commons license, unless indicated otherwise in a credit line to the material. If material is not included in the chapter's Creative Commons license and your intended use is not permitted by statutory regulation or exceeds the permitted use, you will need to obtain permission directly from the copyright holder.

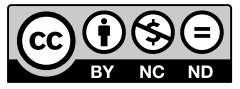

